mean value of $\lambda 10^{6}$ finally adopted was $3^{\cdot 66}$, differing very little from the above result.

But if we examine the matter more closely we find that the velocities for round 9 , given by the two chronographs at $A$ were $907^{\circ} 4$ and $8877^{\circ} \mathrm{m}$.s., showing a difference of $20^{\circ} 2 \mathrm{~m}$. s., or $66^{\circ} 3$ f.s. ; and for round 10 there was a difference in the measured velocities at $B$ of $19.4 \mathrm{~m} . \mathrm{s}$., or $63^{\circ} 6 \mathrm{f} . \mathrm{s}$. ; while at $C$ there was only one velocity measured for all four rounds, by one instrument ; so that the determination of the value of $\lambda$ in both the above cases was made to depend upon one solitary velocity, measured by an instrument manifestly unreliable. But at both $A$ and $B$ the velocity adopted was an average of the results of eight measured velocities. Consequently these velocities at $A$ and $B$ may be expected to give a trust worthy value of $\lambda$ over range $A B$, if the experiment be of any importance. Substituting we find $\lambda_{10} 0^{6}=2.58$, something very differ ent from its adopted value $3 \cdot 66$. So that, according to this group 3, the Newtonian law of resistance holds for velocities between 900 and $438 \mathrm{~m} . s$., and for velocities between 853 and 438 m.s., but not for velocities between 900 and 853 m.s.! Group 2 is still more inconsistent.

Gen. Mayevski is also the author of an attempt to express the laws of the resistance of the air to elongated projectiles from extensive experiments said to have been made at Meppen in $188 \mathrm{I}$. The projectiles were more pointed, and the standard density of the air adopted was less than those used in England. Capt. Ingalls, having reduced Gen. Mayevski's coefficients to English measures for convenience of comparison, remarks, "It will be seen that these coefficients are less than the corresponding coefficients derived from Bashforth's values of $K$, given above. This is undoubtedly due to the different forms of projectiles used in the two series of experiments, and particularly to the difference in the shapes of the heads" (p. 21). My values of $K$ were derived from about 350 rounds, each of which in general furnished from 8 to Io consistent records, and gave numerous values of $K$ by the help of a single chronograph. And the values of $K$ used in the above tables are the means of $40,30,20$, Io, \&c., independent determinations of $K$ for each velocity. Beyond a doubt they express accurately the average results of the rounds fired.

Although the shooting of recent guns is said to have been improved, it is doubtful whether the coefficients of resistance will require any sensible reduction on that account for long ranges. For, as we have seen, however steady may be the initial motion of an elongated shot, the lateral action of the air must soon set up a gyratory motion of the shot, and therefore the axis of the shot must become oblique to the direction of motion. And we are told that a slight initial unsteadiness of the shot becomes corrected, so that it steadies down in its flight. This we might expect from the nature of the action of the air on an elongated projectile rotating about its axis, which tends to place the axis approximately in the direction of the motion of the shot. But, if it should be found necessary to reduce the coefficient of resistance, this, as I have said, can be effected by writing $K \sigma$ instead of $K$, where $\sigma$ is less than $\mathrm{r}$. But inasmuch as we have to use $\frac{d^{2}}{w} \times K \sigma=\frac{d^{2}}{w} \sigma \times K$, we must first calculate the value of $\frac{d^{2}}{w}$, and then use the tabular numbers in the usual manner.

F. BASHFORTH

\section{PLANTS CONSIDERED IN RELATION TO THEIR ENVIRONMENT}

THAT great differences of constitution are to be found among plants is at once evident-differences affecting internal structure, external form, and habit of life.
Those of structure and form at first seem likely to be correlated, and no doubt such relation to a large extent does obtain, but still it is not at all exact, differences of form occurring between plants whose internal structure closely agrees. The study of the environment of the particular plant enables us to see that this must be taken into account in tracing the changes that have made it what it is, each plant having a power of adaptation to circumstances which determines the form which it assumes, which modifies, though with extreme slowness, its internal structure, and which leads in course of time to the recognition of new species.

Looking at plants from this point of view, we notice at once great differences between those which flourish in water and those whose home is on land. These, again, show diversities between those whose habit is terrestrial and those which are epiphytic, while others are noticeable whose habit of life is more or less completely parasitic, and whose constitution and structure are much modified in consequence.

A typical land plant will be seen to consist of a stem, branching continually, bearing a variable but usually very large number of leaves, and continuous below with a root or system of roots emberlded in the soil. The stem will be characterised by a great development of wood, rigidity being thus secured. The leaves will be noticeable especially for their great extent of surface in relation to their bulk, and will show, generally on their under surfaces, though very frequently on both, a large number of stomata. The roots will be woody, like the stem, and towards their ultimate terminations will be found to bear a varying number of delicate root hairs, by means of which they are enabled to discharge their special function of absorption of water.

This plan of construction is considerably deviated from by plants whose habit is aquatic. The stiffness so essential to a land plant, which has to resist storms of wind, is not at all essential to a water one, which has rather 10 adapt itself to varying currents of water. More flexibility, and that of a rather different kind, is needed by the stem. We find, consequently, that the rigidity of an aquatic plant is mainly arrived at by the development of turgid parenchymatous tissue containing typically large intercellular spaces, while the woody tissue largely disappears. The intercellular spaces in most cases form a very elaborate system, as may be seen on examining the petioles of the large white water-lily (Nymphcea alba), the stem of the common mare's-tail (Hippuris), or the whole plant of different species of Potamogeton. The number of the fibro-vascular bundles is much less than would be the case in the stem of a land plant of similar dimensions, but the most noticeable difference is the relalatively much smaller amount of woody tissue in each bundle. This difference of internal constitution may be connected also with a functional difference associated with the enviromment. The woody tissue of a plant is concerned with the transmission of water upwards from the roots to the leaves. In the case of an aquatic plant this is not needed to anything like the extent to which it is in an ordinary tree, and hence a further reason for the disappearance of woody elements. Nor is it only the stem which has been affected by the habitat. The character of the root will be found to vary. This is best seen in noticing the effect of allowing the root of an ordinary land plant to come into contact with a quantity of water. By its constitution it is fitted to absorb only the hygroscopic water surrounding particles of soil. The first effect of the contact with excess of water is to cause the root to perish; but after a time new roots are developed which can utilise the moisture they now are in contact with, and which in turn are unable to avail themselves of the hygroscopic water which before was necessary. Both kinds of roots may be seen sometimes on plants which have been growing close to pipe-drains, some having penetrated the 
drain, and so come into contact with water in quantity; others remaining unchanged, and utilising only the water of the soil. Such differences may be noticed also in the case of hyacinths, grown some by water culture in glasses, others in ordinary earth. The former roots are larger and more succulent than the latter. A difference also may be seen in the development of the root-hairs, though a very definite statement about this can hardly be made. Still, in allied species, and often in individuals of the same species, the hairiness of the roots increases with increasing sunlight, dryness, and airiness of the spot in which the plants are growing.

The leaves also undergo much structural modification. Many plants have leaves which are totally submerged, and these are able to resist the action of the water, which would soon destroy ordinary leaves, whose constitution fits them to live only in air. Some amphibious plants show this peculiarity well. They grow generally in marshy places, or on the banks of streams, by which they are often submerged. Such a plant, having its land form, possesses leaves which die on being submerged, but later it puts out other leaves which are not injured. In Lycopus europaus and in Lythrum Salicaria there is also a histological difference between the stems grown in water and those grown in air. Two layers of cells containing no chlorophyll are developed in the watery specimens deep down in the cortical parenchyma The outer layers of tissue perish, and these new cells then serve to protect the tissues within. In the leaves of water plants also, other peculiarities are noticcable. Generally chlorophyll is developed in the epidermis, a fact which is perhaps connected with the slight amount of evaporation taking place The position of the stomata and their relative number in different case; is also closely connected with their habit of life. This may be well seen in Marsilea, whose leaves, though generally raised above the surface of the water, are sometimes to be found floating on the surface. The aërial leaves have stomata on both upper and under surfaces, but the swimming ones have them only on the upper surface, and have then three times the number that the same surface of the aërial leaf possesses. It is easy to show that the change is the result of the change in the environment, for if a piece of the plant, possessing quite young leaves, be submerged and kept under the surface, the young leaves will develop into swimming-leaves, and not aërial ones. In other water plants with large floating leaves the same disposition of stomata may be seen. Generally on sub-aërial leaves it is the lower surface which shows them in far the larger quantity. The environment of the plants then seems to have a great influence on their distribution, that arrangement being followed which is best suited to keep the stomata dry.

A curious adaptation of structure to environment is seen in the roots of the epiphytic orchids and aroids. These are aërial in habit, hanging freely downwards. Not coming into contact with water in the same way as either aquatic or terrestrial plants, they have no root-hairs. There is a development of tissue met with in them which enables them to absorb and avail themselves of the moisture in the atmosphere. Instead of the usual single-layered epidermis, they are covered by a many-layered velamen made up of numerous cells fitting closely together, of the description known as tracheides. The usual cuticle or secretion from the outer walls of the epidermis, which is always very little developed in roots, is here altogether absent ; the membranes of the cells are usually colourless, and the cells themselves contain air. This layer absorbs water quickly, supplying the plant with moisture.

The influence of the environment on the forms of leaves, as well as on their structure, can be well seen also in aquatic plants. The swimming leaves show certain general resemblances, their form being more or less rounded, and not as a rule lobed or cut; they are, too, usually of fair dimensions. In the case of submerged leaves we find differences which are connected with the conditions noticeable in the water. Thus, in a rapid stream they are generally long and very much divided, while in stagnant water this is not the case. Three species of the genus Ranunculus especially exhibit a gradation in this respect. R. divaricatus is a denizen of stagnant water; $R$. aquatilis is found in slowly-flowing streams; R. fluitans in rapid ones. The divisions of the leaf are longest in the last case and shortest in the first, the second being intermediate. $R$. aquatilis is an amphibious form, and shows well how environment decides the character of the adult plant. When growing in a pool it has its leaves in fairly long divisions, the lobes being rounded and the internodes long. If the pool should dry up, it changes gradually, the new leaves being less divided and the divisions becoming flattened, while the nodes are nearer together. The epidermis, which in the water form had almost square walls, now becomes serpentine. Growing so, it produces in due time its flowers and seeds, and these latter reproduce the land form. If the pool again becomes filled with water, a reversion speedily takes place, and again the characteristics of the water form are seen. The two are, in fact, easily converted from the one into the other.

Not only is the correspondence between environment, form, and structure seen in the species of Ranunculus already alluded to, but the whole genus can be divided into two sections, those of terrestrial and those of aquatic habit, so nearly allied to each other in all points of socalled systematic importance that they are now included together under the common name Ranunculus, and yet extremely dissimilar in form and structure of the vegetative parts. The same difference in amount of woody tissue as has been alluded to above can be seen most strikingly by comparison of sections of the stem of $R$. repens with those of the stem of $R$. fluitans.

Turning now from aquatic plants to those which, though alike terrestrial, are yet situated amid very different surroundings, the effect of the environment can easily be traced. Take, first, the plants which inhabit regions in which habitually the air contains very little moisture. 'These may be affected in several different ways-the most conspicuous modification perhaps being the different forms of succulent plants, such as Mesembryanthemum. In these the leaves have lost the usual ratio between surface and bulk; they are now thick and fleshy, their internal parenchyma being very succulent or pulpy their outer layers leathery, with comparatively few stomata, and a great reduction of the system of intercellular spaces typically found in the leaf. Their environment has led to such a structure as will enable them to make the most of the limited supply of moisture, great facilities being seen for storing it, and precautions taken against its escape. Similar adaptations, but affecting the stems and not the leaves, are found, e.g., in the branching, fleshy Opuntias, while we have also large, thick, fleshy leaves in the aloes and agaves of such regions. The genus Euphorbia has some strange representatives here. There are several hundred species of this genus, inhabiting all parts of the world, and all characterised by the peculiar structure of the flower familiar to us in the common spurge of our gardens. The great majority of the species are annual or perennial herbs, with slender unarmed stems bearing great numbers of scattered, sessile, simple leaves. The comparatively few members of the genus which inhabit the regions of little moisture have become so extremely modified in their vegetative parts as to closely resemble cactuses. E. canariensis especially has taken on this peculiar habit, developing enormously its stem and branches, the former becoming in some cases 20 feet high, and ceasing to produce leaves, while the branches are plentifully supplied with prickles. 
A curious modification in the cells of the leaf is seen sometimes in some species of Oxalis. In plants grown in well-shaded spots the cells of the pallisade parenchyma are not so much elongated as in those exposed to more light, but are more conical. In the beech too a similar difference is noted. In the sun the leaf is smaller and thicker, and has several layers of pallisade parenchyma, while in the shade it is large, but thin, and the pallisade layer is single.

Looking still at terrestrial plants, the general character of the vegetation in different regions illustrates well the general correspondence between environment and struc. ture. In the tropics we find vegetation luxuriant, huge trees with evergreen leaves, masses of interlacing climbers, a great tendency of the smaller plants to become shrubby, even some annuals simulating the bushes of temperate regions; the presence of palms, tree-ferns, \&c. Higher in latitude these disappear, bushes are more numerous; the trees become less luxuriant and more compact, the leaves smaller and more rigid; annuals are found in larger proportion, while mosses and lichens make their appearance. Still higher, where the influence of winter begins to be felt, the trees have as a rule deciduous leaves, which do not cover them for more than half the year. Where the leaves remain evergreen, as in the Coniferæ, they are specially constructed to resist cold, being strongly cuticularised and altered in form so that the ratio of surface to bulk is much lessened. In the pines especially they are much elongated, becoming almost needle-like in shape. Their structure is adapted especially to check loss of water by evaporation, and to protect the delicate parenchyma of the interior from the access of the cold.

Various modifications of structure accompany also a parasitic habit of life. Here the effect of the environment must be taken to include all the various interferences with the normal habits of plants brought about by the changes in the mode of nutrition which the parasite now pursues. The modifications will be seen to be greater the more complete the parasitism. We may consider what are perhaps the most striking cases, those found among flowering plants. Of these we have certain Scrophulariaceæ which show but little modification. They take only part of their nourishment from their hosts, being furnished with means of living exactly like other plants. The dependence of the different species of Orobanche on the host is more complete. The outward form of the plant is there ; the long stem, bearing small leaves. In accordance with the mode of nutrition, all the food being absorbed from the host, tha power of absorbing food or obtaining energy from without the latter has gone ; the leaves contain no chlorophyll, and are consequently brown and shrivelled. In Cuscuta the process of degradation has gone still further, even the leaves having disappeared. The degradation does not affect merely the vegetative structure, but the reproductive organs also suffer, as may be seen in the common mistletoe. This change, however, seems only incidentally to be connected with the environment, being rather the result of the disturbance of the constitutional equilibrium brought about by the changes in nutrition.

A comparison of lower forms of parasitic habit with others which, though about as high in the scale, do not depend on a host for support, reveals similar degradation brought about by the nature of the mode of life Their power of independent growth has much decreased, their cells often appear to contain no nuclei, or these are made out with difficulty; they have no chlorophyll, nor any of the other colouring matters which are present in the nonparasitic forms.

Some curious modifications of structure are associated also with different climbing plants. These are not of so general a nature as those already alluded to, being noticeable only on particular species. In Ampelopsis hederacea, and in $A$. Veitchii the curved tips of the tendrils, after touching a surface, form adhesive disks, which secrete and pour out a resinous cement which attaches the tendril to the surface. Bignonia capreolata has a similar but more elaborate development, while Ficus repens, which climbs like the ivy by rootlets, exudes similar material from its rootlets, this being somewhat of the nature of caoutchouc.

Not only the vegetative parts of plants thus exhibit modifications of structure according to the nature of their environment, but the same thing can be seen especially with regard to the structure of the reproductive organs. The ways in which these are adapted to different modes of fertilisation would however pass far beyond the limits of this article.

\section{NOTES}

Prof. Melsens, the distinguished chemist, has died at Brussels, at the age of seventy-two.

By the death of the Rev. W. W. Newbould, F.L.S., which took place on April r6, at Kew, at the age of sixty-seven, a figure has passed away very familiar to the frequenters of the meetings and library of the Linnean Society, the British Museum herbarium and reading-room, and the herbarium at Kew. At the time of his student-days at Cambridge, where he was a pupil of Prof. Henslow, Mr. Newbould acquired a love of botany, which became the recreation, and latterly the pursuit, of his life. His interest was, however, confined to a study of our native British plants, the limitation of the species, and especially their geographical distribution. Several of our local county floras owe much to his co operation; and of some particular. groups of plants he had a very exact knowledge. But his speciality was an intimate acquaintance with the botanical bibliography of this country; in his knowledge especially of the older literature he was almost unrivalled.

MANY will regret to learn of the death of Thomas Edwards, the Banff naturalist, so well known through his Life by Mr. Samuel Smiles. Edwards was born on Christmas Day, 1814, at Gosprrt, Portsmouth, where his father, a private in the Fifeshire Militia, was stationed after returning from the Peninsular War. Early in life Thomas Edwards showed indications of a great love of animals, insects, and creatures of every description. He made extensive excursions in search of specimens, and many amusing anecdotes are told to illustrate his extreme fondness for even the most repulsive subjects in the anirual creation. At eleven he was apprenticed to a shoemaker, and at the age of eighteen he had undergone many severe trials. He joined the Militia, but his love of insects proved fatal to his military ambition. In his twentieth year Edwards went to work as a shoemaker at Banff, and there he pursued so successfully his researches in natural history that he added a great deal to his scientific store of knowledge. For fifteen years he carried on the most of his researches by night, and he had many narrow escapes by reason of the eagerness with which he pursued his object. He completed, however, a splendid collection, and in 1846 exhibited it in Aberdeen. The exhibition was a failure, and he had to sell the collection for $20 l$. to defray the expenses. He then set to work to form another collection, and was mo t successful. His researches added greatly to the knowledge of natural history, as he embodied his new discoveries in papers written to scientific magazines. In I866 Edwards was elected a member of several scientific societies. Latterly he had acted as Curator of Banff Museum. After the publication of his biography by Smiles, Edwards's genius was publicly recognised by a presentation of 333l. made to him in Aberdeen, and he was awarded by the Queen a pension of $50 l$. a year. 